\title{
PENGARUH LINGKUNGAN KERJA TERHADAP KINERJA MELALUI KOMPETENSI SDM SEBAGAI VARIABEL INTERVENING PADA UKM KERIPIK TEMPE MALANG
}

\author{
Ratih Indriyani ${ }^{{ }^{*}}$, Monica Dewi ${ }^{2}$ \\ 1,2 Program Manajemen Bisnis, Program Studi Manajemen, Universitas Kristen Petra \\ Jl. Siwalankerto 121-131, Surabaya \\ E-mail: ${ }^{1}$ ranytaa@petra.ac.id; ${ }^{2}$ monicadewisusanto@gmail.com \\ *Penulis korespondensi
}

\begin{abstract}
Abstrak
Penelitian ini bertujuan untuk mengetahui pengaruh dari lingkungan kerja terhadap kompetensi sumber daya manusia, kompetensi sumber daya manusia terhadap individual performance dan pengaruh dari lingkungan kerja terhadap terhadap individual performance pada UKM Keripik Tempe Sanan Malang. Pengumpulan data menggunakan angket. Sampel yang digunakan 100 orang karyawan UKM Keripik Tempe Sanan, Malang. Teknik pengambilan sampel menggunakan teknik purposive sampling. Metode analisis yang digunakan adalah Partial Least Square (PLS). Hasil penelitian menunjukkan bahwa lingkungan kerja berpengaruh signifikan terhadap kompetensi sumber daya manusia, kompetensi sumber daya manusia berpengaruh terhadap individual performance dan lingkungan kerja berpengaruh signifikan terhadap terhadap individual performance.
\end{abstract}

Kata kunci: Lingkungan kerja, kompetensi SDM, individual performance.

\begin{abstract}
This study aims to determine the effect of the work environment on the human resource competency, cmpetence of human resource competency on individual performance and the influence of the work environment on individual performance in SME Keripik Tempe Sanan Malang. Questionnaires were used for data collection. The sample was 100 employees work in Keripik Tempe Sanan Malang. The sampling technique is purposive sampling. The analytical method used is Partial Least Square (PLS). The results showed that the work environment had a significant effect on the competence of human resources, human resource competencies had an effect on individual performance, work environment had a significant effect on individual performance.
\end{abstract}

Keywords: Work environment, human resource competency, individual performance.

\section{PENDAHULUAN}

Industri kreatif memiliki peran penting dalam pertumbuhan ekonomi di Indonesia. Pada tahun 2015, sektor kreatif menyumbangkan 852 triliun rupiah terhadap PDB nasional (7,38\%), menyerap 15,9 juta tenaga kerja $(13,90 \%)$, dan nilai ekspor US\$19,4 miliar (12,88\%) (Abuzah, 2019). Sektor ekonomi kreatif menunjukkan perkembangan yang signifikan terhadap perekonomian nasional dari tahun 2010-2015 yaitu sebesar 10,14\% per tahun. Hal ini membuktikan bahwa ekonomi kreatif memiliki potensi untuk berkembang di masa mendatang. Industri kreatif adalah industri yang mencakup 14 subsektor usaha di Indonesia Malang dikenal sebagai kota pendidikan dan kota wisata. Dalam perkembangannya, Malang sekarang mulai dikenal sebagai salah satu kota kreatif Indonesia. Berbagai kegiatan industri kreatif berkembang di kota Malang, seperti aktivitas industri kreatif yang bergerak pada sub sektor kuliner/olah makanan (Yusadi et al, 2018). Salah satu industri pengolahan makanan yang terkenal di Malang adalah industri pengolahan keripik tempe yang salah satunya diproduksi di Sanan. Keripik tempe semakin dikenal sebagai oleh-oleh khas Malang dan banyak dicari oleh wisatawan (Ferdinand, 2014). Produk keripik tempe berhasil menembus pasar luar negeri dengan sistem penjualan baik secara online maupun offline baik secara tradisional secara pribadi dan terintegrasi dengan persatuan atau komunitas karyawan tempe.

Industri kreatif merupakan industri yang didukung kreativitas, keterampilan dan bakat individu. Industri ini berkembang melalui melalui penciptaan dan pemanfaatan daya kreasi dan daya cipta individu (Rosmadi, 2005). Untuk dapat mendukung proses pekerjaan dalam sektor pengolahan makanan diperlukan intensitas pengerjaan karyawan dan kompetensi yang dibutuhkan. Kompetensi menunjukkan 
karakteristik individu yang berkaitan dengan kinerja efektif dalam situasi pekerjaan tertentu. Menurut Spencer dan Spencer (1993) menjelaskan kompetensi terdiri dari dimensi, yaitu pengetahuan, sikap dan keterampilan. Ketiga hal ini dianggap sebagai indikator pengukuran yang tepat dalam menilai kompetensi individu. Kompetensi karyawan dalam lingkup manajemen sumber daya manusia memiliki kaitan dengan kemampuan dalam proses perencanaan, pengorganisasian, pengarahan serta pengawasan pada berbagai hal yang berkaitan dengan pengadaan, pengembangan, pemberian motivasi, pengintegrasian, pemeliharaan serta pemutusan kerjasama (Untari, 2014). Kompetensi adalah aspek penting yang dapat mendukung karyawan dalam organisasi untuk memiliki kinerja yang baik terutama selaku individu dalam organisasi (June dan Mahmood, 2011)

Keterbatasan kompetensi sumber daya manusia, peralatan serta berbagai fasilitas pendukung menjadi kendala UKM secara umum. Aktivitas produksi keripik tempe pelaku UKM di Sanan dikerjakan secara home industry dimana melibatkan orang terdekat seperi anggota keluarga, tetangga dalam satu wilayah tersebut (Muhammad, 2013). Produk keripik tempe telah berkembang pada berbagai varian rasa. Keripik tempe telah dibuat secara otodidak dan telah dikerjakan sebagai usaha yang berlangsung secara turun temurun (Ferdinand, 2014). UKM Keripik Tempe Sanan Malang sebagai industri kecil yang berkembang dimana saat ini omset penjualan rata-rata perhari sebesar 1,250,000 per pengrajin sehingga diperkirakan omset perbulan mencapai 30 juta lebih. Tingkat penjualan tersebut menunjukkan bahwa permintaan pasar produk keripik tempe Sanan cukup besar sehingga kualitas produksi harus dijaga. Kualitas produksi membutuhkan kestabilan operasional produksi dengan kinerja karyawan yang stabil serta maksimal, kompetensi karyawan yang baik, dan lingkungan kerja yang memadai. (wawancara dengan Syaiful Bakrie, Sekretaris UKM Keripik Tempe Sanan Malang). Hasil wawancara menunjukkan salah satu kendala lingkungan kerja adalah keterbatasan fasilitas untuk bekerja secara cepat dan rapi, terkait masalah kompetensi yakni karyawan dengan kelas yang pemula berbeda dengan kelas menengah bahkan profesional ditinjau dari kemampuan sehingga berdampak pada kinerja individu sebagai karyawan (individual performance)

Proses keberhasilan kegiatan usaha khususnya UKM yang maksimal tidak luput dari kondisi lingkungan kerja yang nyaman dan kondusif. Menurut Dawis dan Lofquist (1984) dalam Haslberger dan Thomas (2014) menjelaskan lingkungan kerja dalam hal ini seperti kenyamanan budaya kerja, tanggapan perusahaan pada kinerja karyawan, motivasi, kompetensi dan sebagainya dapat memunculkan situasi dimana karyawan akan memiliki rasa keterkaitan yang tinggi dan akan meningkatkan perilaku umum, kemampuan, kompetensi serta potensi diri untuk tetap bekerja sama dengan organisasi tersebut sebagai bentuk rasa kepuasan kerja dibandingkan bekerja di tempat, organisasi atau perusahaan lain. Lingkungan kerja positif diketahui dapat menimbulkan semangat kerja dan juga sebaliknya jika lingkungan kerja negatif maka dapat mengurangi semangat kerja (Pawirosumarto et al, 2017).

Individual performance merupakan sebuah hasil yang dicapai oleh individu sebagai karyawan dalam kriteria tertentu menurut sebuah aturan pekerjaan dengan proses kerja dengan cara terus-menerus baik secara individu maupun kelompok (Hussein, 2017) dimana kinerja individu sebagai karyawan merupakan sebuah output yang efisien dan kerap dihubungkan dengan produktivitas ditujukan dengan hasil optimal. Hasil kerja menunjukkan sebuah bagian dari kinerja dengan membandingkan antara hasil kerja dan standar kerja yang telah ditetapkan. Permasalahan UKM pada umumnya yakni berkaitan dengan produktivitas khususnya pada kualitas barang maupun jasa yang dihasilkan. Keterbatasan kompetensi sumber daya manusia, peralatan serta berbagai fasilitas pendukung yang pada umumnya menjadi kendala UKM.

Penelitian ini bertujuan untuk meneliti pengaruh lingkungan kerja terhadap kinerja karyawan melalui kompetensi sumber daya manusia. Penelitian dilakukan pada karyawan yang bekerja pada sentra industri keripik tempe di Sanan, Malang

\section{TINJAUAN PUSTAKA}

\section{Lingkungan Kerja}

Lingkungan kerja merupakan bagian dari keselamatan kerja para karyawan terkait dengan kondisi lapangan yang menjadi bagian terpenting dalam proses penciptaan sebuah lingkungan kerja (Jayaweera, 2015). Pada penelitian Samani et al (2015) dijelaskan bahwa keberhasilan organisasi dapat digambarkan secara lapangan dari kondisi lingkungan kerja dimana faktor lingkungan kerja dapat berdampak pada hasil kerja. (Yusuf dan Metiboba, (2012) menyatakan bahwa lingkungan kerja tidak hanya fisik, namun juga semua anggota organisasi di dalamnya. Lingkungan kerja terdiri dari 3 komponen yaitu lingkungan teknis, lingkungan manusia, dan lingkungan organisasi. Masalah lingkungan kerja merupakan aspek luas yang 
dianggap sebagai prioritas dalam mengatur berbagai faktor terkait penyelenggaraan aktivitas kerja pada sebuah organisasi (Dharmanegara et al., 2016). Lingkungan kerja positif diketahui dapat menimbulkan semangat kerja dan juga sebaliknya jika lingkungan kerja negatif maka dapat mengurangi semangat kerja (Pawirosumarto et al, 2017).

\section{Kompetensi SDM}

Menurut Spencer dan Spencer (1993) kompetensi merupakan landasan dasar karakteristik individu dengan mengindikasikan cara berperilaku atau berpikir dengan menyesuaikan situasi serta mendukung tiga dimensi karakteristik kompetensi yakni pengetahuan, sikap (perilaku) dan keterampilan (skill). Kompetensi merujuk pada keterampilan karyawan yang ia miliki, kompetensi terlihat dalam perilaku karyawan. Perilaku karyawan sebagai cerminan kompetensi menunjukkan keterampilan apa yang dimiliki karyawan (Nikolajevaite dan Sabaityte, 2016). Oswald (2012) menjelaskan bahwa kompetensi menunjukkan tindakan dalam menggunakan kemampuan, pengetahuan dan keterampilan yang dimiliki sesuai standar yang ditetapkan. Kesesuaian individu melaksanakan standar tersebut dengan bidang ilmu yang dikuasai menunjukkan kompetensi yang dimiliki baik. Kompetensi sumber daya manusia menggambarkan suatu kemampuan sumber daya manusia untuk melaksanakan atau melakukan pekerjaan yang dilandasi oleh keterampilan, pengetahuan serta sikap kerja.

\section{Individual Performance}

Individual performance menunjukkan tenaga kerja atau karyawan secara individu mampu bekerja secara responsif, adil dan efisien untuk mencapai hasil kinerja terbaik dimana performance dianggap komposit dilengkapi dengan empat elemen yakni ketersediaan, produktivitas, kompetensi dan responsif khususnya pada penyelesaian berbagai masalah produksi (Oswald, 2012). Menurut Jayaweera (2015) mendefinisikan kinerja sebagai sebuah perilaku atau kegiatan yang dilakukan untuk mencapai tujuan dan sasaran organisasi dimana membawa kesuksesan bagi bisnis khususnya pada individu dalam menyelesaikan tugas pekerjaan guna mencapai kepuasan. Kinerja pada khususnya untuk individu dalam hal terkait dengan sumber daya manusia menunjukkan pada hasil yang diperoleh individu pada periode tertentu dibandingkan dengan standar kerja dimana setiap organisasi diwajibkan melakukan penilaian atau evaluasi untuk mengukur produktivitas yang dicapai (Amiroso, 2015).
Performance memiliki arti sebagai hasil kerja secara kualitas dan kuantitas yang berhasil dicapai oleh seseorang sebagai karyawan atau pegawai dalam melaksanakan tugas sesuai dengan tanggung jawab yang diberikan (Dharmanegara et al., 2016).

\section{Lingkungan kerja dan Kompetensi SDM}

Menurut Yani dan Indrawati (2016), lingkungan kerja dapat mempengaruhi kompetensi SDM. Lingkungan kerja yang mendukung akan memudahkan individu dalam menyelesaikan pekerjaan yang diberikan. Individu dengan lingkungan kerja yang mendukung turut memunculkan rasa percaya diri sehingga terpacu untuk bekerja secara optimal. Kondisi lingkungan kerja yang secara fisik dan non fisik dianggap mampu menciptakan situasi kerja yang lebih menyenangkan dan mendukung karyawan dalam bekerja Lingkungan fisik dapat meliputi ketersediaan alat, ruangan kerja yang kondusif. Lingkungan kerja ini akan meningkatkan kemampuan, ketrampilan serta potensi karyawan. Lingkungan nonfisik seperti hubungan antara atasan dengan karyawan dan sesama karyawan akan mendorong terjadinya komunikasi timbal balik sehingga terdapat pesan, informasi, pengajaran, pengetahuan, pola pikir baru yang diberikan pada karyawan. Hali ini bisa dijadikan bekal dalam peningkatan ketrampilan, skill serta kompetensi karyawan sebagai sumber daya manusia organisasi.

H1: Diduga lingkungan kerja berpengaruh signifikan terhadap kompetensi SDM

\section{Pengaruh Kompetensi SDM Terhadap Individual Performance}

Individu dapat memiliki perilaku didukung oleh berbagai alasan dan tujuan yang berbeda-beda. Kompetensi pada dasarnya merupakan salah satu faktor individu dalam berperilaku yang dianggap sebagai sebuah perwujudan pola pikir. Kompetensi diperlukan untuk mendukung peran khusus terkait kinerja pada sebuah pekerjaan (Couhan dan Srivastava, 2014). Amiroso (2015) menjelaskan bahwa kompetensi dan karakteristik individu sebagai karyawan muncul dalam bentuk pengetahuan, keterampilan dan perilaku dimana kompetensi yang baik sebagai seorang karyawan maka individu tersebut akan melakukan tugas secara profesional, efektif dan efisien. Karyawan dengan pemahaman (pengetahuan), ketrampilan, sikap serta skill yang baik dinilai mampu mengontrol perilaku, dengan pola pikir yang baik didukung pemahaman yang tinggi maka berbagai masalah terkait dengan hambatan dalam produktivitas maupun kinerja dapat 
diselesaikan dengan baik serta seefektif dan seefisien mungkin.

H2: Kompetensi SDM berpengaruh terhadap Individual Performance

\section{Pengaruh Lingkungan Kerja Terhadap Individual Performance}

Menurut Bagus et al (2016) dijelaskan bahwa lingkungan kerja memberikan pengaruh pada kinerja serta operasional karyawan pada sebuah organisasi. Hal ini berdampak baik secara langsung maupun tidak langsung pada tingkat produktivitas organisasi. Lingkungan kerja yang positif berdampak pada peningkatan kinerja karyawan. Lingkungan kerja dirancang sedemikian rupa sehingga mempengaruhi produktivitas pada pekerjaan. Kondisi lingkungan kerja dengan sistem standar kerja yang tersistematis didukung fasilitas alat kerja dirasakan oleh karyawan mampu memberikan beberapa dampak salah satunya peningkatan produktivitas. Hal ini sesuai dengan penelitian Jayaweera (2015) yang menjelaskan bahwa lingkungan kerja dapat memberikan dampak serta pengaruh pada kinerja karyawan. Lingkungan kerja dinilai mampu memberikan dampak pada kinerja individu sebagai karyawan (individual performance). Karyawan memiliki persepsi yang baik dengan lingkungan kerja sehingga memiliki harapan yang baik pada masa depan kesejahteraan mereka terkait dengan bonus, upah dan sebagainya. Kondisi kenyamanan serta penciptaan lingkungan kerja yang baik maka mendukung adanya penyesuaian pada peningkatan kompetensi serta produktivitas karyawan.

H3: Lingkungan Kerja berpengaruh terhadap Individual Performance.

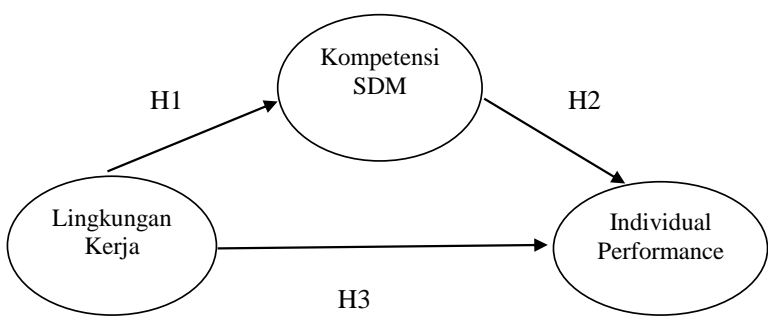

Gambar 1. Model Penelitian

\section{METODE PENELITIAN}

\section{Jenis Penelitian}

Jenis penelitian yang digunakan adalah kurangtitatif dengan pendekatan kausalitas. Pendekatan kausalitas yakni pendekatan penelitian untuk melihat pengaruh antara variabel satu dengan variabel lain. Metode kuantitatif menggunakan penelitian populasi serta sampel tertentu dengan analisis data secara statistik. Analisis data ini ditujukan untuk menjawab rumusan masalah dan menguji kebenaran hipotesis (Sugiyono, 2016). Penelitian ini menunjukkan hubungan sebab akibat antara variabel eksogen dan variabel endogen. Penelitian ini menguji pengaruh lingkungan kerja dan kompetensi SDM terhadap individual performance.

\section{Populasi dan Sampel Penelitian}

Populasi sering kali disebut dengan wilayah generalisasi yang terdiri dari objek maupun subjek dimana memiliki kuantitas dan karakteristik tertentu. Hal ini ditetapkan oleh penelitian, yang kemudian dapat ditarik kesimpulan (Sugiyono, 201). Populasi pada penelitian ini adalah seluruh karyawan pada UKM Keripik Tempe Sanan Malang sebanyak 1750 orang.

Sampel merupakan bagian kecil dari jumlah serta karakteristik yang dapat mewakili populasi (Sugiyono, 2016). Penentuan sampel menggunakan Metode Slovin dengan perhitungan rumus sebagai berikut:

$n=\frac{N}{1+N e^{2}}$

Keterangan:

$n=$ jumlah sampel

$N=$ jumlah populasi yang diketahui

$e=$ Presisi yang ditetapkan $(10 \% / 0,1)$

Jumlah sampel yang akan di ambil dalam penelitian ini:

$n=\frac{1750}{1+\left(1750 \times 0,1^{2}\right)}$

$n=\frac{1750}{18,5}$

$n=94,5 / 100$ orang

Hasil perhitungan sampel responden sebesar 94,5 dan dibulatkan menjadi 100 sehingga responden yang akan digunakan dalam penelitian ini sebesar 100 karyawan. Teknik pengambilan sampel pada penelitian ini adalah menggunakan teknik non probability sampling yakni sampling purposive yaitu berdasarkan kriteria karyawan yang bekerja di UKM Keripik Tempe Sanan Malang.

Variabel bebas merupakan variabel yang mempengaruhi atau yang menjadi penyebab perubahan atau timbulnya variabel eksogen atau terikat. Variabel bebas dalam penelitian ini adalah lingkungan kerja.

\section{Lingkungan Kerja $(X)$}

Lingkungan kerja menggambarkan berbagai hal yang berkaitan dengan karyawan dalam bekerja baik secara fisik maupun non fisik yang dapat mempengaruhi produktivitas atau kinerja karyawan baik langsung maupun tidak langsung. Variabel lingkungan kerja 
diukur berdasarkan tiga indikator menurut Pawirosumarto et al. (2017) sebagai berikut:

1. Work atmosphere yakni hal ini berkaitan dengan kondisi atau suasana tempat bekerja yang berhubungan dengan kenyamanan karyawan dalam melakukan berbagai aktivitas pekerjaan yang bersifat rohani, mental maupun psikologis.

2. Relationship with colleagues yakni hubungan kerja meliputi sistem komunikasi antar karyawan, kerjasama tanpa adanya perselisihan.

3. Work facilities yakni berbagai fasilitas, peralatan yang sifatnya kebendaan yang disediakan dan ditujukan untuk mendukung kelancaran kerja sesuai dengan kebutuhan para karyawan sebagai penunjang proses produksi.

\section{Individual Performance (Y)}

Variabel terikat adalah merupakan variabel yang dipengaruhi atau yang menjadi akibat, karena adanya variabel bebas. Variabel terikat pada penelitian ini adalah individual performance.

Individual performance merupakan hasil kerja secara kualitas dan kuantitas yang berhasil dicapai oleh seseorang sebagai karyawan. Indikator individual performance sesuai dengan penelitian Dharmanegara et al. (2016) sebagai berikut:

1. Quantity of work merupakan penilaian atas kurangtitas dari jumlah barang yang berhasil diproduksi dari keseluruhan hasil kerja

2. Quality of work yakni hasil kerja dilakukan oleh individu dalam memenuhi standar kualitas yang ditetapkan

3. Time accuracy berkaitan dengan ketepatan serta kecepatan dalam menyelesaikan berbagai pekerjaan

4. Attendance menunjukkan partisipasi serta kehadiran maupun keterlibatan individu dalam menyelesaikan berbagai masalah pekerjaan

5. Work cooperation dimana dalam hal ini berkaitan dengan kerjasama yang ditunjukkan individu dengan rekan kerja lain maupun atasan

\section{Variabel Intervening}

Variabel intervening adalah variabel yang secara teoritis mempengaru hubungan antara variabel independen dengan variabel dependen menjadi hubungan yang tidak langsung dan tidak dapat diamati serta diukur. Variabel intervening pada penelitian ini adalah kompetensi SDM

\section{Kompetensi SDM (Z)}

Kompetensi SDM merupakan landasan dasar karakteristik individu dengan mengindikasikan cara berperilaku atau berpikir dengan menyesuaikan situasi. Menurut Spencer dan Spencer (1993) indikator pengukuran kompetensi SDM adalah sebagai berikut:

1. Pengetahuan merupakan kesanggupan seseorang dalam melaksanakan suatu kegiatan atau pekerjaan yang dipercayakan pada pihak individu atau pekerja tersebut.

2. Sikap merupakan perwujudan kompetensi pegawai. Sikap merupakan suatu cara mereaksi terhadap rangsangan dari luar yang timbul dari seseorang atau dari lingkungan.

3. Keterampilan (skill). Aspek keterampilan sumber daya manusia terdiri dari dua aspek yang perlu yakni hard skill dimana berkaitan dengan kemampuan atau kompetensi inti dari sebuah bidang ilmu yang bersifat fisik atau jasmani.

\section{Metode dan Sumber Pengumpulan Data}

Pengumpulan data dalam penelitian ini menggunakan angket Skala pengukuran dalam penelitian meng-gunakan skala likert yang berhubungan pendapat dan penilaian responden. Skala likert merupakan alat ukur interval dengan lima tingkatan dalam penilaian skor dari angka 1-5.

\section{Teknik Analisis Data}

Teknik analisis data dalam penelitian ini menggunakan: analisis Partial Least Square (PLS) adalah salah satu metode statistika SEM berbasis varian yang didesain untuk menyelesaikan permasalahan spesifik pada data, seperti contoh ukuran sampel penelitian kecil, adanya data yang hilang (missing values), dan multikolinearitas.

\section{HASIL PENELITIAN DAN PEMBAHASAN}

\section{Convergent dan Discriminant Validity}

Berdasarkan pada Tabel 1, suatu indikator konstruk dikatakan memenuhi convergent validity jika mem-punyai nilai loading $>0,70$, hal ini digunakan untuk mengukur variabel laten. Tabel 1 , menunjukan hasil dari pengujian convergent validity pada variabel lingkungan kerja, kompetensi SDM dan individual performance, dapat dijelaskan bahwa loading faktor yang dilihat pada original sampling dapat diketahui bahwa semua indikator konstruk masing-masing variabel yaitu variabel lingkungan kerja, kompetensi SDM dan individual performance memiliki loading factor yang lebih besar dari 0,70 dengan demikian indikator tersebut dapat dinyatakan valid sebagai pengukur variabel latennya. 
Tabel 1. Convergent dan Discriminant Validity

\begin{tabular}{lccc}
\hline & $\begin{array}{c}\text { Lingkungan } \\
\text { Kerja }\end{array}$ & $\begin{array}{c}\text { Individual } \\
\text { Performance }\end{array}$ & $\begin{array}{c}\text { Kompetensi } \\
\text { SDM }\end{array}$ \\
\hline$X_{1.1}$ & $\mathbf{0 , 8 7 4}$ & 0,688 & 0,715 \\
$X_{1.2}$ & $\mathbf{0 , 8 5 6}$ & 0,755 & 0,754 \\
$X_{1.3}$ & $\mathbf{0 , 8 1 5}$ & 0,706 & 0,688 \\
$X_{2.1}$ & $\mathbf{0 , 8 1 3}$ & 0,761 & 0,721 \\
$X_{2.2}$ & $\mathbf{0 , 8 6 6}$ & 0,727 & 0,758 \\
$X_{2.3}$ & $\mathbf{0 , 7 9 9}$ & 0,745 & 0,724 \\
$X_{3.1}$ & $\mathbf{0 , 7 5 7}$ & 0,704 & 0,729 \\
$X_{3.2}$ & $\mathbf{0 , 7 6 9}$ & 0,662 & 0,662 \\
$Y_{1.1}$ & 0,728 & $\mathbf{0 , 8 5 3}$ & 0,783 \\
$Y_{1.2}$ & 0,745 & $\mathbf{0 , 8 4 1}$ & 0,691 \\
$Y_{2.1}$ & 0,839 & $\mathbf{0 , 8 5 6}$ & 0,832 \\
$Y_{2.2}$ & 0,669 & $\mathbf{0 , 7 3 5}$ & 0,597 \\
$Y_{3.1}$ & 0,637 & $\mathbf{0 , 7 4 9}$ & 0,719 \\
$Y_{3.2}$ & 0,762 & $\mathbf{0 , 8 7 2}$ & 0,789 \\
$Y_{4.1}$ & 0,650 & $\mathbf{0 , 7 6 8}$ & 0,704 \\
$Y_{4.2}$ & 0,748 & $\mathbf{0 , 8 3 0}$ & 0,724 \\
$Y_{5.1}$ & 0,761 & $\mathbf{0 , 8 5 0}$ & 0,728 \\
$Y_{5.2}$ & 0,723 & $\mathbf{0 , 8 2 7}$ & 0,696 \\
$Y_{5.3}$ & 0,685 & $\mathbf{0 , 8 4 9}$ & 0,706 \\
$Z_{1.1}$ & 0,744 & 0,757 & $\mathbf{0 , 8 4 8}$ \\
$Z_{1.2}$ & 0,670 & 0,715 & $\mathbf{0 , 8 0 6}$ \\
$Z_{1.3}$ & 0,743 & 0,702 & $\mathbf{0 , 8 1 9}$ \\
$Z_{1.4}$ & 0,673 & 0,662 & $\mathbf{0 , 7 9 8}$ \\
$Z_{2.1}$ & 0,770 & 0,756 & $\mathbf{0 , 8 2 4}$ \\
$Z_{2.2}$ & 0,755 & 0,723 & $\mathbf{0 , 8 5 0}$ \\
$Z_{2.3}$ & 0,618 & 0,646 & $\mathbf{0 , 7 2 2}$ \\
$Z_{3.1}$ & 0,745 & 0,780 & $\mathbf{0 , 8 3 3}$ \\
$Z_{3.2}$ & 0,698 & 0,774 & $\mathbf{0 , 7 8 7}$ \\
$Z_{3.3}$ & 0,668 & 0,612 & $\mathbf{0 , 7 9 1}$ \\
\hline & & &
\end{tabular}

Berdasarkan pada Tabel 1, discriminant validity setiap variabel dalam mengukur item pernyataan hal ini ditunjukkan oleh cross loadings. Dapat diketahui masing-masing indikator memiliki cross loading (terhadap dimensi atau variabel yang diukur) yang lebih besar daripada nilai cross loading terdapat dimensi atau variabel lainnya. Sehingga indikator tersebut dikatakan valid untuk mengukur dimensi atau variabel yang bersesuaian jika nilai cross loading > 0,70 .

Tabel 2. Uji Reliabilitas (Composite Reliability)

\begin{tabular}{lc}
\hline & Composite Reliability \\
\hline Lingkungan Kerja & 0,942 \\
Kompetensi SDM & 0,950 \\
Individual Performance & 0,958 \\
\hline
\end{tabular}

Berdasarkan hasil pengujian item pengukuran dikatakan reliabel jika memiliki nilai koefisien alpha lebih besar dari 0,6. Tabel 2 diatas menunjukkan bahwa nilai reliabilitas konsistensi internal, untuk koefisien alpha masing-masing variabel dalam setiap variabel dinyatakan reliabel karena lebih besar dari 0,6 , dengan demikian item pengukuran pada masingmasing variabel dinyatakan reliabel dan selanjutnya dapat digunakan dalam penelitian.

Tabel 3. Hasil Uji AVE

\begin{tabular}{ll}
\hline & AVE \\
\hline Lingkungan Kerja & 0,672 \\
Kompetensi SDM & 0,654 \\
Individual Performance & 0,676 \\
\hline
\end{tabular}

Average Variance Extracted (AVE) adalah salah satu syarat uji validitas berdasarkan nilai rata-rata extracted setiap variabel. Diharapkan nilai AVE $>0,5$, menunjukkan bahwa telah memenuhi evaluasi validitas konvergen. Berikut hasil uji AVE.

Tabel 4. $R$-Square

\begin{tabular}{lc}
\hline & R Square \\
\hline Lingkungan Kerja & \\
Kompetensi SDM & 0,772 \\
Individual Performance & 0,830 \\
\hline
\end{tabular}

Hasil $R$ square bernilai 0,830 atau $83,0 \%$. Hal ini menunjukkan keragaman variabel lingkungan kerja dan kompetensi SDM dapat mempengaruhi individual performance sebesar $83,0 \%$. Sisanya $17,0 \%$ dipengaruhi variabel lain diluar penelitian. Hasil $R$ square kompetensi SDM sebesar 0,772 atau 77,2\% dimana lingkungan kerja dapat mempengaruhi kompetensi SDM sebesar 77,2\%. Sisanya sebesar 22,8 \% merupakan kontribusi variabel lain yang tidak dibahas.

\section{Uji Hipotesis}

Uji hipotesis digunakan untuk menentukan kausalitas yang dikembangkan dalam model yaitu pengaruh variabel eksogen terhadap variabel endogen. Pengujian signifikansi dapat diketahui melalui $t$ statistic lebih besar dari nilai kritis 1.96 sesuai pada tabel.

Tabel 5. Uji Hipotesis

Path Coefficients

\begin{tabular}{lcccc}
\hline & $\begin{array}{c}\text { Original } \\
\text { Sample }\end{array}$ & $\begin{array}{c}\text { Sample } \\
\text { Rata-ratata }\end{array}$ & $\begin{array}{c}\text { Standard } \\
\text { Deviation }\end{array}$ statistics \\
\hline $\begin{array}{l}\text { Kompetensi SDM } \rightarrow \\
\text { Individual Perfor- } \\
\text { mance }\end{array}$ & 0,482 & 0,483 & 0,085 & 5,678 \\
$\begin{array}{l}\text { Lingkungan Kerja } \\
\rightarrow \text { Individual }\end{array}$ & 0,458 & 0,458 & 0,087 & 5,268 \\
$\begin{array}{l}\text { Performance } \\
\begin{array}{l}\text { Lingkungan Kerja } \\
\rightarrow \text { Kompetensi SDM }\end{array}\end{array}$ & 0,879 & 0,879 & 0,022 & 40,774 \\
\hline
\end{tabular}




\section{Pengaruh Lingkungan kerja terhadap kompetensi SDM}

Hasil dari pengujian yang tertera pada tabel di atas dapat diketahui bahwa nilai $t$-statistic lingkungan kerja terhadap kompetensi SDM adalah 40,774. Hasil pengujian tersebut menunjukkan bahwa nilai $t$ statistic $>1,96$. Hal ini dapat diartikan bahwa lingkungan Kerja berpengaruh langsung terhadap kompetensi SDM.

\section{Pengaruh Kompetensi SDM terhadap individual performance}

Hasil dari pengujian yang tertera pada tabel di atas dapat diketahui bahwa nilai $t$-statistic kompetensi SDM terhadap individual performance adalah 5,678. Hasil pengujian tersebut menunjukkan bahwa nilai $t$ statistic> 1,96 dan. Hal ini dapat diartikan bahwa kompetensi SDM berpengaruh langsung terhadap individual performance.

\section{Pengaruh Lingkungan kerja terhadap individual performance}

Pada hasil pengujian dapat diketahui bahwa nilai $t$-statistic lingkungan kerja terhadap individual performance adalah 5,268. Hasil pengujian tersebut menunjukkan bahwa nilai $t$-statistic $>1,96$. Hal ini dapat diartikan bahwa lingkungan kerja berpengaruh langsung terhadap individual performance.

Tabel 6. Konversi Diagram Jalur

\begin{tabular}{lccc}
\hline \multicolumn{1}{c}{ Variabel } & \multicolumn{3}{c}{ Effect } \\
\cline { 2 - 4 } & Direct & Indirect & Total \\
\hline $\begin{array}{l}\text { Kompetensi SDM } \rightarrow \text { Individual } \\
\quad \text { Performance }\end{array}$ & 0,482 & - & 0,482 \\
$\begin{array}{c}\text { Lingkungan Kerja } \rightarrow \text { Individual } \\
\quad \text { Performance }\end{array}$ & 0,882 & - & 0,882 \\
$\begin{array}{c}\text { Lingkungan Kerja } \rightarrow \text { Kompetensi } \\
\quad \text { SDM }\end{array}$ & 0,879 & - & 0,879 \\
$\begin{array}{c}\text { Lingkungan Kerja } \rightarrow \text { Individual } \\
\quad \text { Performance }\end{array}$ & 0,424 & $0,424 * 0,482$ & 0,204 \\
\hline
\end{tabular}

\section{PEMBAHASAN}

\section{Pengaruh lingkungan kerja terhadap kompetensi} SDM

Hasil pengujian menunjukkan bahwa nilai $t$ statistic lingkungan kerja terhadap kompetensi SDM adalah 40,774. Hasil pengujian tersebut menunjukkan bahwa nilai $t$-statistic $>1,96$ dan nilai koefisien sebesar 0,879 yang bernilai positif. Hal ini dapat diartikan bahwa lingkungan kerja berpengaruh langsung secara signifikan dan positif terhadap kompetensi SDM.
Proses keberhasilan kegiatan usaha khususnya UKM yang maksimal tidak luput dari kondisi lingkungan kerja yang nyaman dan kondusif. Hal ini sesuai dengan penelitian Oswald (2012) dijelaskan bahwa lingkungan kerja dapat mempengaruhi kompetensi SDM. Lingkungan kerja yang mendukung memudahkan individu dalam menyelesaikan pekerjaan yang diberikan. Individu dengan lingkungan kerja yang mendukung turut memunculkan rasa percaya diri sehingga terpacu untuk bekerja secara optimal. Di sisi lain lingkungan kerja buruk menyebabkan individu enggan melanjutkan pekerjaan melihat berbagai dampak, beban dan minim penghargaan atau apresiasi yang diperkiran akan diterima. Lingkungan bekerja yang baik akan mendorong terjadinya komunikasi timbal balik sehingga terdapat pesan, informasi, pengajaran, pengetahuan, pola pikir baru yang diberikan pada karyawan lain dimana bisa dijadikan bekal dalam peningkatan keterampilan (skill) juga serta kompetensi SDM karyawan sebagai sumber daya manusia yang dikelola oleh organisasi.

\section{Pengaruh kompetensi SDM terhadap individual performance}

Hasil pengujian menunjukkan bahwa nilai $t$ statistic kompetensi SDM terhadap individual performance adalah 5,678. Hasil pengujian tersebut menunjukkan bahwa nilai $t$-statistic $>1,96$ dan nilai koefisien sebesar 0,482 yang bernilai positif atau searah dimana kenaikan variabel kompetensi SDM akan berdampak pada peningkatan individual performance sebesar 0,482. Hal ini dapat diartikan bahwa kompetensi SDM berpengaruh langsung secara signifikan dan positif terhadap individual performance. Kompetensi SDM menunjukkan kemampuan untuk melaksanakan peran dan tugas, kemampuan mengintegrasikan pengetahuan, keterampilan, sikap, dan nilai pribadi serta kemampuan untuk membangun pengetahuan dan keterampilan yang didasarkan pada pengalaman dan pembelajaran. Individu dapat menerapkan perilaku didukung oleh berbagai alasan dan tujuan yang berbeda-beda. Kompetensi SDM pada dasarnya merupakan salah satu faktor individu dalam berperilaku yang dianggap sebagai sebuah perwujudan pola pikir. Kompetensi SDM diperlukan untuk mendukung kinerja pada sebuah pekerjaan. Hal ini sesuai dengan penelitian Amiroso (2015) bahwa kompetensi SDM dan karakteristik individu sebagai pekerja atau karyawan muncul dalam bentuk pengetahuan, keterampilan dan perilaku. Penelitian tersebut mendapatkan hasil bahwa individu yang memiliki kompetensi akan mampu melakukan tugas secara profesional, efektif dan efisien. Karyawan dengan pemahaman 
(pengetahuan), keterampilan, sikap serta skill yang baik dinilai mampu mengontrol sikap, dengan pola pikir yang baik didukung pemahaman yang tinggi maka berbagai masalah terkait dengan hambatan dalam produktivitas maupun kinerja dapat diselesaikan dengan baik serta seefektif dan seefisien mungkin.

\section{Pengaruh lingkungan kerja terhadap individual performance}

Hasil penelitian menunjukkan bahwa nilai $t$ statistic lingkungan kerja terhadap individual performance adalah 5,268 dan nilai koefisien sebesar 0,458 yang bernilai positif atau searah dimana kenaikan variabel lingkungan kerja akan berdampak pada peningkatan individual performance sebesar 0,458. Hasil pengujian tersebut menunjukkan bahwa nilai $t$ statistic $>1,96$. Hal ini dapat diartikan bahwa lingkungan kerja berpengaruh langsung secara signifikan dan positif terhadap individual performance.

Lingkungan kerja yang berkaitan dengan sistem kerja yang baik, sikap kerjasama antar karyawan, perlakuan pemilik UKM terhadap karyawan dengan memberikan bantuan melalui pembelajaran maka dapat meningkatkan kemampuan karyawan tersebut. UKM memiliki peran penting dalam membangun kesadaran karyawan dalam keterlibatan pencapaian tujuan serta ukuran kinerja. Menurut Samani et al (2015) lingkungan kerja yang berkualitas akan meningkatkan kinerja karyawan. Kondisi lingkungan kerja dapat berpengaruh mendorong karyawan untuk bekerja dengan baik, tepat serta maksimal

Hal ini sesuai dengan penelitian Jayaweera (2015) lingkungan kerja dapat memberikan dampak serta pengaruh pada kinerja individu sebagai karyawan (individual performance). Lingkungan kerja dinilai mampu memberikan dampak dalam meningkatkan kinerja individu sebagai karyawan (individual performance). Karyawan yang tampil lebih baik, dengan fasilitas, pakaian dan kondisi tempat kerja yang baik mendorong karyawan untuk melakukan inovasi, bekerja secara baik, rapi dan cepat. Karyawan memiliki persepsi yang baik dengan lingkungan kerja sehingga memiliki harapan yang baik pada masa depan kesejahteraan mereka terkait dengan bonus, upah dan sebagainya. Penelitian Dharmanegara et al (2016) menjelaskan bahwa lingkungan kerja memberikan pengaruh pada kinerja karyawan pada sebuah organisasi. Hal ini berdampak baik secara langsung maupun tidak langsung pada tingkat produktivitas organisasi atau perusahaan. Lingkungan kerja yang positif memiliki dampak pada peningkatan kinerja karyawan. Kondisi lingkungan kerja dengan sistem standar kerja yang tersistematis didukung fasilitas alat kerja dirasakan oleh karyawan mampu memberikan beberapa dampak salah satunya peningkatan produktivitas.

\section{KESIMPULAN DAN SARAN}

\section{Kesimpulan}

Penelitian yang telah dilakukan mendapatkan hasil bahwa variable yang diteliti memiliki pengaruh yang signifikan terhadap variable lainnya. Hasil penelitian menunjukkan bahwa lingkungan kerja berpengaruh positif dan signifikan terhadap kompetensi SDM. Kompetensi SDM berpengaruh positif dan signifikan terhadap individual performance. Selanjutnya penelitian ini juga menunjukkan hasil bahwa ingkungan kerja berpengaruh positif dan signifikan terhadap individual performance.

\section{Saran}

Pemilik UKM disarankan agar selalu memperhatikan lingkungan kerja dalam hal keamanan, kebersihan, juga kelengkapan fasilitas. Hal ini bisa dilakukan dengan cara melakukan pemeriksaan rutin. Kompetensi SDM sebaiknya ditingkatkan dalam memahami tugas pekerjaan. Karyawan perlu diberikan pelatihan terkait dengan pengelolaan diri, pengembangan diri, potensi dan evaluasi secara berkala untuk memberikan pemahaman yang baik terkait dengan tugas pekerjaan yang dilakukan. Variabel lingkungan kerja, terkait dengan indikator relationship with colleagues, pada item pernyataan hubungan antar rekan kerja yang baik mendapatkan nilai terendah sehingga pemilik harus senantiasa memperhatikan kondisi psikis terkait dengan hubungan antar karyawan. Pemilik usaha dapat membangun keakraban antara karyawan sehingga mudah bekerjasama. Untuk penelitian selanjutnya dapat menambah variabelvariabel yang mempengaruhi individual performance UKM Keripik Tempe Sanan Malang seperti variabel motivasi kerja, kepuasan kerja, keterlibatan karyawan dan sebagainya.

\section{DAFTAR REFERENSI}

Abuzah, F. (2019). Data statistik dan hasil survei ekonomi kreatif 2016. Badan Ekonomi Kreatif dan Badan Pusat Statistik.

Amiroso, J., \& Mulyanto. (2015). Influence of discipline, working environment, culture of organization and competence on workers' performance 
through motivation, job satisfaction (Study in regional development planning board of Sukoharjo Regency). European Journal of Business and Management, 7(36), 86-95.

Chouhan, V S \& Srivastava, S. (2014). Understanding competencies and competency modeling - A literature survey. IOSR Journal of Business and Management, 1, 14-22.

Dharmanegara, I. B. A., Sitiari, N. W., Wirayudha, ID. G. N. (2016). Job competency and work environment: The effect on job satisfaction and job performance among SMEs worker. Journal of Business and Management, 18(1), 19-26.

El-Kot, R. J. B. G. (2010). Work engagement among managers and professionals in Egypt. African Journal of Economic and Management Studies, $1(1), 42-57$.

Ferdinand (2014). Strategi pengembangan klaster usaha mikro kecil dan menengah keripik tempe di Sanan Malang. Jurnal Aplikasi Manajemen, 14(1).

Ghozali, I. (2012). Partial least square konsep dan aplikasi menggunakan PLS. Semarang: Universitas Diponegoro.

Haslberger, C., \& Thomas. (2014). Managing performance abroad a new model for understanding expatriate ajustment. New York: Routledge Taylor and Francis Group.

Hussein, F. (2017). Kepuasan kerja dan kinerja pegawai, budaya organisasi, perilaku pemimpin dan efikasi diri. Yogyakarta: Elmatera.

Jayaweera, T. (2015). Impact of work environmental factors on Job Performance, Mediating Role of Work Motivation: A Study of Hotel Sector in England. International Journal of Business and Management, 10(3), 271-278.

June, S., \& Mahmood, R. (2011). The relationship between role ambiguity, competency and personjob fit with the job performance of employees in the service sector SMEs in Malaysia. Business Management Dynamics, 1(2), 79-98.

Muhammad, T. (2013). Hubungan tingkat modal sosial terhadap tingkat pendapatan pelaku UKM (Studi pada sentra industri keripik tempe Sanan Malang). Jurnal FISIP Universitas Brawijaya Malang, 2, 1-9.
Nikolajevaite, M. dan Sabaityte, E. (2016). Relationship between employees' competencies and job satisfaction: british and lithuanian employees. Psychology Research, 6(11), 684-692.

Oswald, A. (2012). The effect of working environment on workers' performance: The case of reproductive and child health care providers in Tarime District. (Master thesis dissertation, Muhimbili University of Health and Allied Sciences).

Pawirosumarto, Purwanto \& Rachmad. (2017). The effect of work environment, leadership style and organizational culture towards job satisfaction and its implication towards employee performance in Parador Hotels and Resorts, Indonesia. International Journal of Law and Management, 7(1), 1-16.

Roswadi, M L N. (2015). Industri kreatif dalam menghadapi pasar bebas asean tahun 2015 . Jurnal Wawasan Hukum, 30 (1).

Samani, S.A., Razid, R.Z.A, Sofian (2015). Perceived level of personal control over the work environment and employee satisfaction and work performance. Performance Improvement, 54(9).

Spencer, L., \& Spencer, S. M. (1993). Competence at work, model for superior performance. Canada: John Wiley \& Sons, Inc.

Sugiyono. (2016). Metode penelitian kuantitatif, kualitatif dan $R \& D$. Bandung: CV Alfabeta.

Untari, S. (2014). Pengaruh kompetensi dan lingkungan kerja Terhadap kinerja karyawan. Jurnal Ilmu dan Riset Manajemen, 3(10), 1-16.

Yani, A., \& Indrawati, A. (2016). Pengaruh lingkungan kerja dan motivasi kerja terhadap kompetensi guru bersertifikasi di SMK Negeri 1 Pasuruan. Jurnal Pendidikan Bisnis dan Manajemen, 2(1), 58-74.

Yusadi, R, Waluyo, B S, Setyono, D A. (2018). Rencana aksi pengembangan industri kreatif kuliner berbasis media online di kota malang. Jurnal Tata Kota dan Daerah, 10(2).

Yusuf N. \& Metiboba S. (2012). Work environment and job attitude among employees in a Nigerian work organization. Journal of Sustainable Society, 1(2), 36-43 